\title{
Pengembangan Tanaman Keladi Tikus (TyPhonium Flagelliforme LODD.) ASAL INDONESIA SEBAGAI OBAT ANTIKANKER
}

\section{${ }^{1}$ Nesti Fronika Sianipar, ${ }^{2}$ Ragapadmi Purnamaningsih, ${ }^{3}$ Rosaria}

\author{
${ }^{1}$ Jurusan Teknologi Pangan, Universitas Bina Nusantara, Jl. Alam Sutera Boulevard No. 1, Tangerang \\ 15325. \\ ${ }^{2}$ Balai Besar Penelitian dan Pengembangan Bioteknologi dan Sumber Daya Genetik Pertanian \\ (BB-Biogen), Jl. Tentara Pelajar No. 3A, Bogor 16111. \\ ${ }^{3}$ Alumni Mahasiswa Jurusan Biologi, Fakultas Sains dan Teknologi, Universitas Pelita Harapan, Jl. MH. \\ Thamrin Boulevard 1100, Tangerang 15811 \\ e-mail: ${ }^{1}$ nestipro@yahoo.com; ${ }^{2}$ raga_padmi@yahoo.com; ${ }^{3}$ rosaria201105@gmail.com
}

\begin{abstract}
Abstrak. Keladi tikus merupakan tanaman obat yang bermanfaat sebagai obat kanker. Keladi tikus memiliki kandungan kimia diantaranya adalah alkaloid, flavonoid, saponin, steroid dan glikosida. Keladi tikus memiliki keragaman genetik yang rendah. Untuk meningkatkan keragaman telah dilakukan mutasi seca ra fisik melalui iradiasi sinar gamma pada kultur in vitro keladi tikus. Media MS dengan penambahan $0.5 \mathrm{mg} / \mathrm{l} 2.4 \mathrm{D}$ dan $0.1 \mathrm{mg} / \mathrm{l}$ kinetin menghasilkan jumlah tunas terbanyak yaitu 14.38 plantlet. Kalus embriogenik mutan dihasilkan melalui induksi dengan sinar gamma 6 gray. Kalus embriogenik diregenerasikan menjadi 59 tunas mutan. Plantlet mutan yang dihasilkan telah dideteksi dengan marka molekuler RAPD dan menunjukan perubahan genetik. Beberapa galur mutan yang telah diperoleh memiliki keragaman tinggi secara morfologi dan genetik. Keragaman genetik klon mutan generasi pertama(MV1) sampai generasi keempat (MV4) yang diperoleh telah dideteksi secara genetik molekuler dengan RAPD. Beberapa klon MV5 (mutan stabil) memiliki kandungan senyawa bioaktif antikanker tinggi berdasarkan GC-MS. Analisis GC-MS menunjukkan bahwa tanaman mutan mengalami peningkatan kandungan senyawa antikanker dibanding kontrol serta senyawa baru yang tidak ditemukan di kontrol. Beberapa klon unggul yang dihasilkan perlu dikembangkan sebagai bahan baku obat antikanker. Keladi tik us unggul bermanfaat untuk mencegah dan mengobati penyakit kanker pada masyarakat Indonesia.
\end{abstract}

Kata kunci: keladi tikus, kultur jaringan, iradiasi gamma, marka RAPD

\section{Pendahuluan}

Keladi tikus (Typhonium flagelliforme Lodd.) merupakan tanaman obat herbal yang termasuk famili Araceae (Essai, 1986) dengan kandungan agen detoksifikasi dan antikanker. Keladi tikus merupakan tanaman asli Indonesia dan telah digunakan masyarakat sebagai obat tradisional. Senyawa yang berkhasiat dalam tanaman ini adalah alkaloid, saponin, steroid, dan glikosida (Syahid, 2007). Seluruh bagian tanaman keladi tikus mengandung senyawa antikanker yaitu baik pada akar, umbi, batang, maupun daun (Choo et al., 2001).

Keladi tikus bermanfaat dalam mengobati kanker paru-paru dan payudara (Lai et al., 2010), hati (Lai et al., 2008), leukemia (Mohan et al., 2010), usus, kelenjar prostat, dan leher rahim (Hoesen, 2007). Aktivitas antikanker keladi tikus juga terlihat dalam mencegah kanker payudara dan rahim (Syahid \& Kristina, 2007). Aktivitas biologis lain yang dimiliki oleh tanaman keladi tikus antara lain efek antibakteri, antioksidan (Mohan 
et al., 2008), toksik terhadap Artemia salina (Sianipar et al., 2013a), dan memicu apoptosis (Lai et al., 2008).

Permasalahan yang dihadapi dalam pengembangan keladi tikus untuk bahan baku obat antikanker adalah rendahnya keragaman genetik keladi tikus asal Indonesia karena perbanyakan klonal vegetatif secara konvensional. Rendahnya keragaman genetik berakibat pada rendahnya diversitas kandungan senyawa bioaktif keladi tikus (Syahid, 2008). Peningkatan diversitas kandungan senyawa bioaktif keladi tikus dapat dilakukan melalui kultur in vitro dengan cara induksi mutasi pada populasi sel somatik atau tunas pucuk. Induksi mutasi dapat dilakukan antara lain melalui mutasi secara fisik dengan menggunakan iradiasi sinar gamma.

Hasil iradiasi gamma dengan dosis 6 gray pada populasi sel somatik kalus keladi tikus asal Bogor menunjukkan respon pertumbuhan tunas putatif yang beragam (Sianipar et al., 2013b). Plantlet mutan in vitro keladi tikus asal bogor telah dideteksi terjadi perubahan genetik berdasarkan analisis secara molekuler dengan metode Randomly Amplified Polymorphic DNA (RAPD) (Sianipar et al, 2015a). Ada 37 galur mutan putatif generasi pertama (MV1) di green house yang telah dikarakterisasi secara morfologi dan dianalisis dengan RAPD sehingga diperoleh 15 galur. 15 galur yang dianalisis menunjukkan keragaman dan perubahan genetik dari tanaman kontrol (Sianipar et al., 2015b).

Pengembangan keladi tikus sebagai obat antikanker sudah dilakukan dalam beberapa tahapan penelitian untuk meningkatkan kandungan senyawa bahan aktif alami. Penelitian dimulai dari kultur jaringan sel melalui kalus, peningkatan keragaman genetik melalui sel somatik dengan iradiasi gamma, pendeteksian perubahan genetik dengan RAPD, dan pengidentifikasian kandungan senyawa bioaktif dengan GC-MS. Penelitian ini sudah memperoleh tanaman mutan stabil yang memiliki kandungan senyawa bioaktif yang tinggi. Klon mutan yang dihasilkan diharapkan dapat digunakan sebagai bahan baku obat dan minuman fungsional yang bermanfaat untuk kesehatan masyarakat.

Penyakit kanker adalah penyakit yang sangat banyak diderita masyarakat Indonesia sehingga perlu dilakukan pengembangan obat antikanker. Penyakit kanker payudara merupakan penyebab kematian yang paling tinggi pada wanita berdasarkan data Kementrian Kesehatan tahun 2010-2013 (Kementrian kesehatan, 2015). Penelitian ini bertujuan untuk mengembangkan tanaman keladi tikus yang memiliki potensi tinggi sebagai bahan obat antikanker sehingga dapat digunakan masyarakat Indonesia untuk mencegah dan mengobati penyakit kanker.

\section{Metode Penelitian}

\subsection{Teknologi Produksi Bibit melalui Kultur Jaringan Tanaman}

Bahan tanam. Tanaman keladi tikus (Typhonium flagelliforme Lodd.) berasal dari Bogor, Indonesia.

Steriliasi dan inisiasi eksplan. Umbi tanaman keladi tikus dibilas dengan air mengalir untuk membersihkan partikel-partikel tanah yang menempel. Eksplan kemudian direndam dalam 0,25 gram bakterisida dan fungisida dalam $200 \mathrm{ml}$ akuades selama 30 menit, $2.25 \mathrm{mg} / \mathrm{ml}$ rifampicin selama empat jam, $2 \%$ Clorox® bleach selama 15 menit, $1.5 \%$ Clorox® bleach selama 
15 menit, $1 \%$ Clorox ${ }^{\circledR}$ bleach selama sepuluh menit, dan $0.1 \% \mathrm{HgCl} 2$ selama sepuluh menit. Eksplan selanjutnya dibilas sebanyak dua kali dengan air steril lalu ditanam dalam media kultur untuk inisiasi. Media kultur inisiasi menggunakan medium MS0 yang diperkaya dengan sukrosa dan air kelapa.

Multiplikasi eksplan. Eksplan steril dari medium inisiasi disubkultur pada medium multiplikasi. Media multiplikasi menggunakan medium dasar MS0 dan 1/2 MS0 yang diperkaya dengan sukrosa dan air kelapa. Zat pengatur tumbuh berupa BAP diberikan pada kedua jenis medium dasar dengan konsentrasi $0.5 \mathrm{mg} / \mathrm{L}, 1.0 \mathrm{mg} / \mathrm{L}, 1.5$ $\mathrm{mg} / \mathrm{L}, 2.0 \mathrm{mg} / \mathrm{L}$, dan $2.5 \mathrm{mg} / \mathrm{L}$. Jumlah anakan yang terbentuk diamati setiap minggu hingga minggu ke sepuluh dan disubkultur pada media optimal.

Perakaran. Medium perakaran eksplan menggunakan medium dasar MS0 dan $1 / 2$ MS0 yang diperkaya dengan sukrosa dan air kelapa. NAA dengan konsentrasi 0.5 $\mathrm{mg} / \mathrm{L}, 1.0 \mathrm{mg} / \mathrm{L}, 1.5 \mathrm{mg} / \mathrm{L}, 2.0 \mathrm{mg} / \mathrm{L}$, dan $2.5 \mathrm{mg} / \mathrm{L}$ ditambahkan pada medium dasar MS0. Jumlah akar pada setiap eksplan dihitung pada minggu ke sepuluh dan panjang akar dari setiap eksplan diukur.

\subsection{Peningkatan Keragaman Genetik Dengan Mutasi Iradiasi Sinar Gamma}

Analisis Radiosensitivitas Keladi Tikus Terhadap Iradiasi Gamma. Analisis radiosensitivitas dilakukan menggunakan iradiasi Cobalt $60\left({ }^{60} \mathrm{Co}\right)$ dan alat iradiator gamma chamber 4000A di Laboratorium Pusat Aplikasi Teknologi Isotop dan Radiasi (PATIR), Badan Tenaga Nuklir (BATAN) pada dosis 0, 10, 20, dan 30 Gy untuk kalus keladi tikus. Iradiasi pada kalus diulang sebanyak 48 kali, yaitu 12 botol kultur yang berisi empat kalus. Parameter yang diamati adalah persentase plantlet dan kalus hidup pada setiap dosis iradiasi.

Induksi Mutasi Keladi Tikus Melalui Iradiasi Gamma. Nilai LD50 yang diperoleh digunakan sebagai acuan untuk melakukan induksi mutan keladi tikus. Perlakuan iradiasi pada kalus dilakukan sebanyak 20 kali pengulangan (lima botol kultur yang berisi empat kalus keladi tikus) dengan dosis radiasi LD50. Parameter yang diamati adalah persentase hidup kalus. Kalus kemudian diregenerasi hingga membentuk tunas

\subsection{Deteksi Perubahan Genetik dengan Marka Molekuler RAPD}

Isolasi DNA dan Reaksi PCR. Isolasi DNA dilakukan menggunakan prosedur CTAB (Doyle \& Doyle, 1987) yang dimodifikasi. Reaksi PCR dilakukan dengan volume akhir $25 \mu \mathrm{l}$ terdiri dari $5 \mu \mathrm{l} \mathrm{GoTaq} \mathrm{Flexi} \mathrm{Buffer}(5 \mathrm{X}), 2,5 \mu \mathrm{l} \mathrm{MgCl} 2(25 \mathrm{mM})$, $0,5 \mu \mathrm{l}$ PCR Nucleotide Mix $(10 \mathrm{mM}), 1 \mu \mathrm{l}$ primer $(10 \mathrm{pmol} / \mu \mathrm{l}), 0,2 \mu \mathrm{l}$ GoTaq DNA

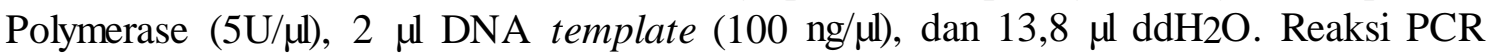
dilakukan menggunakan Techne Thermal Cycler dan program dengan tahapan : predenaturation DNA pada suhu $95^{\circ} \mathrm{C}$ selama 2 menit diikuti dengan 7 siklus yang terdiri atas denaturation pada suhu $95^{\circ} \mathrm{C}$ selama 1 menit, annealing pada suhu $37-34^{\circ} \mathrm{C}$ selama 1 menit (penurunan $0,5^{\circ} \mathrm{C}$ pada tiap siklus), dan extension pada suhu $72^{\circ} \mathrm{C}$ selama 3 menit, kemudian diiikuti dengan 38 siklus yang terdiri atas denaturation pada suhu $95^{\circ} \mathrm{C}$ selama 1 menit, annealing pada suhu $34^{\circ} \mathrm{C}$ selama 1 menit, dan extension pada suhu $72^{\circ} \mathrm{C}$ selama 3 menit, diakhiri dengan siklus final extension pada suhu $72^{\circ} \mathrm{C}$ selama 7 menit dan storage pada suhu $4^{\circ} \mathrm{C}$.

Analisis Data. Setiap fragmen polimorfik yang diperoleh diberikan skoring dengan format data biner 0 dan 1 dan diubah ke dalam bentuk matriks biner. Matriks 
biner digunakan untuk menentukan kesamaan genetik dengan koefisien kesamaan Dice (Nei dan Li, 1979). Analisis kluster dilakukan menggunakan algoritma kluster SAHNUPGMA (Sequential, Agglomerative, Hierarchical, and Nested-Unweighted Pair-Group Method with Arithmetic Mean) pada software NTSYSpc 2.02 (Rohlf, 1998).

\section{Hasil dan Pembahasan}

\subsection{Teknologi Produksi Bibit Melalui Induksi Tunas dari Kalus Embriogenik}

Kalus embriogenik yang dihasilkan pada media proliferasi di subkultur ke media perlakuan MSO yang disuplementasi dengan $0,5 \mathrm{mg} / \mathrm{L}$ BAP dan 0,5, 1, 1,5 mg/L NAA. Hasil yang diperoleh menunjukan bahwa dengan penambahan $1 \mathrm{mg} / \mathrm{L}$ NAA dan 0,5 mg/L BAP dihasilkan jumlah tunas terbanyak, yaitu 14,38 tunas. Jumlah tunas terendah yaitu sebanyak 8,33 tunas dihasilkan pada perlakuan $1.5 \mathrm{mg} / \mathrm{L}$ NAA dan $0.5 \mathrm{mg} / \mathrm{L}$ BAP. Analisis statistik ANOVA menunjukan perbedaan nyata dengan uji Tukey pada tingkat kepercayaan P.0.05 (Tabel 1 dan Gambar 1).

Medium MS merupakan medium yang paling sesuai untuk pertumbuhan keladi tikus. Umbi merupakan bagian tanaman yang umum digunakan sebagai eksplan dalam mikropropagasi keladi tikus. Menurut penelitian yang dilakukan oleh Nobakht et al. (2009), medium MS dengan kandungan 0,5 mg/L BAP dan $1 \mathrm{mg} / \mathrm{L}$ NAA dapat menghasilkan jumlah tunas yang paling banyak untuk setiap eksplan. Medium dengan penambahan BAP dan NAA yang rendah dapat menyebabkan pembentukan planlet yang abnormal dan tidak sempurna. Medium yang paling baik untuk menginduksi mata tunas di dalam penelitian ini adalah medium dengan pemberian NAA sebesar $0,5 \mathrm{mg} / \mathrm{l}$ dan BAP sebesar $0,5 \mathrm{mg} / \mathrm{L}$.

Tabel 1: Pengaruh Berbagai Kombinasi NAA dan BAP terhadap Produksi Tunas Keladi Tikus dari Kalus Embrioge nik Setelah 8 Minggu

\begin{tabular}{|c|c|}
\hline Perlakuan & Jumlah Tunas dari Kalus \\
\hline $1.5 \mathrm{mg} / \mathrm{L} \mathrm{NAA}+0.5 \mathrm{mg} / \mathrm{L} \mathrm{BA}$ & $8,13^{\mathrm{b}}$ \\
\hline $1.0 \mathrm{mg} / \mathrm{L} \mathrm{NAA}+0.5 \mathrm{mg} / \mathrm{L} \mathrm{BA}$ & $14.38^{\mathrm{a}}$ \\
\hline $0.5 \mathrm{mg} / \mathrm{L} \mathrm{NAA}+0.5 \mathrm{mg} / \mathrm{L} \mathrm{BA}$ & $4,25^{\mathrm{b}}$ \\
\hline
\end{tabular}

Keterangan: huruf superscript yang sama menunjukan perbedaan tak nyata berdasarkan uji Tukey pada tingkat kepercayaan P.0.05
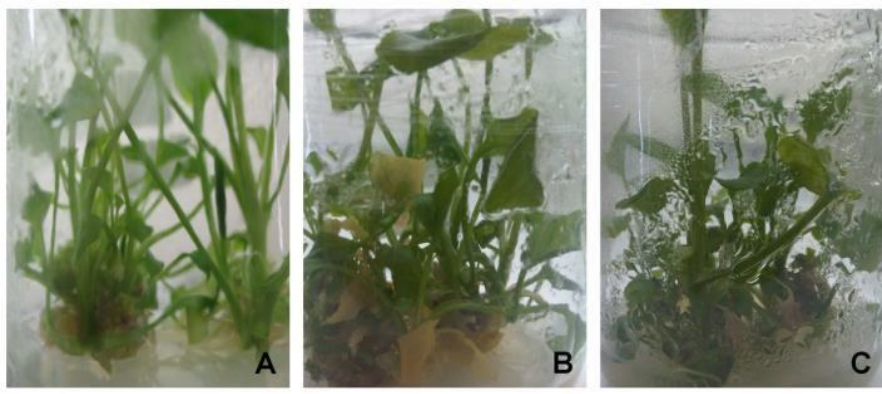

Gambar 1: Induksi Tunas dari Kalus Embriogenik

(A) Penambahan $1 \mathrm{mg} / \mathrm{L}$ NAA $+0.5 \mathrm{mg} / \mathrm{L}$ BAP (B) Penambahan $0.5 \mathrm{mg} / \mathrm{L} \mathrm{NAA}+0.5 \mathrm{mg} / \mathrm{L}$ BAP

(C) Penambahan $0.5 \mathrm{mg} / \mathrm{L} \mathrm{NAA}+0.5 \mathrm{mg} / \mathrm{L} \mathrm{BAP}$. 


\subsection{Analisis Radiosensitivitas Keladi Tikus Terhadap Iradiasi Gamma}

Pada penelitian ini, analisis radiosensitivitas dilakukan pada kalus tanaman keladi tikus. Induksi mutasi dan regenerasi kalus menunjukkan bahan tanam yang paling sesuai untuk diiradiasi sehingga diperoleh mutan hidup keladi tikus. Pemilihan jenis bahan tanam yang akan diiradiasi menentukan keberhasilan iradiasi untuk mendapatkan mutan solid.

Kurva radiosensitivitas kalus keladi tikus memiliki persamaan garis $\mathrm{y}=$ $0,0052 \times 3+0,3959 x 2+10,105 x+100$ dengan nilai LD50 sebesar 6,4 Gy (Gambar 2). Analisis radiosensitivitas pada tanaman keladi tikus belum pernah dilakukan sebelumnya. Hasil penelitian ini menunjukkan bahwa keladi tikus memiliki radiosensitivitas yang berbeda dengan tanaman-tanaman lain.

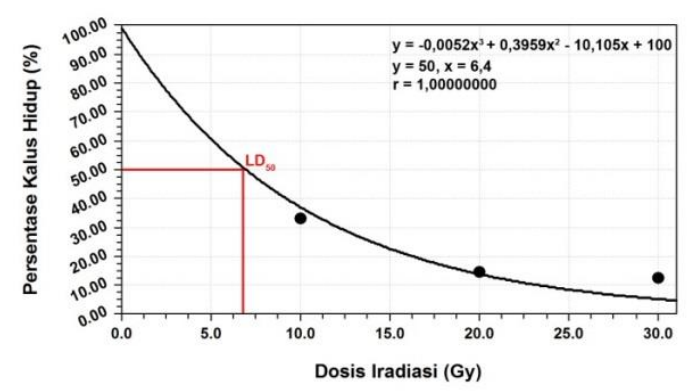

\section{Gambar 2: Kurva Pengaruh Dos is Iradiasi Terhadap Persentase Kalus Hidup}

\subsection{Induksi Mutasi dan Karakter Morfologi Keladi Tikus M1 Asal Kalus}

Induksi mutasi kalus keladi tikus dilakukan pada dosis 0, 10, 20 dan 30 Gy. Induksi mutasi yang dilakukan pada kalus keladi tikus telah berhasil dilakukan dan menghasilkan sembilan kalus yang dapat bertahan dari iradiasi pada dosis 6 Gy, sementara dosis 10 Gy bersifat letal dan menyebabkan kematian pada seluruh kalus yang diiradiasi.

Kalus hidup hasil iradiasi yang diperoleh juga berhasil diregenerasi menjadi tunas dan membentuk plantlet mutan in vitro generasi pertama (M1) (Gambar 3). Penelitian ini berhasil

melakukan regenerasi kalus hasil iradiasi menjadi sebanyak 93 tunas dari total delapan kalus hidup pada dosis 0 Gy, sebanyak 59 tunas dari total sembilan kalus mutan hidup pada dosis 6 Gy, sementara pada dosis 10 Gy tidak membentuk tunas. Kematian seluruh kalus yang diiradiasi pada dosis 10 Gy juga menunjukkan bahwa iradiasi memberikan pengaruh yang merusak terhadap sel- sel pada kalus, sehingga kalus yang bertahan pada dosis 6 Gy merupakan mutan karena dapat bertahan dari kerusakan sel yang terjadi akibat iradiasi. Pada dosis 0 Gy, rata-rata jumlah tunas yang dapat diregenerasi adalah 11,63 tunas per kalus, sementara pada dosis 6 Gy hanya dapat dihasilkan 6,56 tunas per kalus (Gambar 4). 

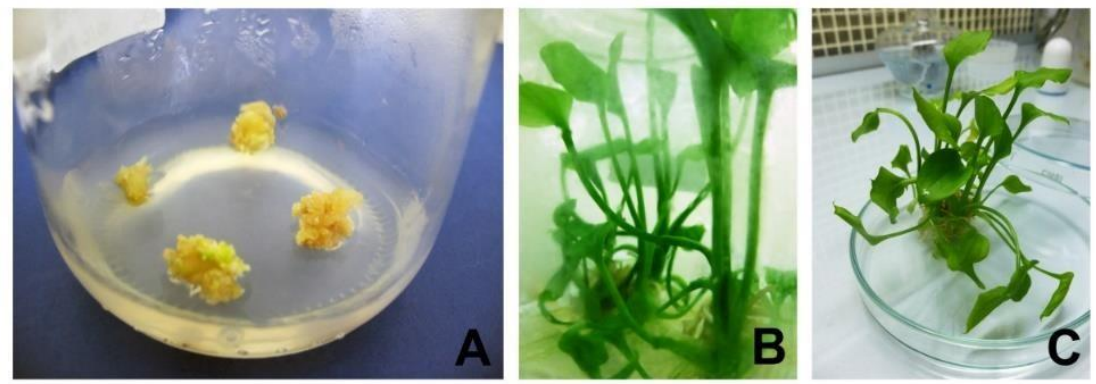

Gambar 3: Proses regenerasi kalus hasil iradiasi 6 Gy

(A) Kalus keladi tikus 1 MSI, (B) Tunas keladi tikus M1 22 MSI, (C) Tunas keladi tikus M1 24 MSI

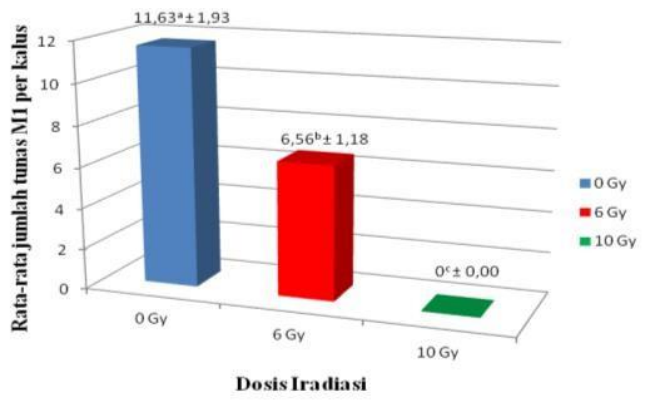

Gambar 4: Rata-rata jumlah tunas keladi tikus M1 per kalus yang berhasil dire generasi se telah diiradiasi gamma pada dosis 0 Gy, 6 Gy, dan 10 Gy.

Iradiasi menyebabkan penurunan kemampuan sel kalus untuk dapat diregenerasi menjadi tunas (Yasmin et al., 2011). Jumlah mutan yang dapat diperoleh dengan pemberian mutagen dipengaruhi oleh efek iradiasi terhadap sel somatik, antara lain viabilitas yang menurun dan abnormalitas pertumbuhan (Puchooa, 2005). Pada penelitian ini, perbedaan yang nyata pada kemampuan regenerasi kalus menjadi tunas menunjukkan bahwa iradiasi menurunkan viabilitas sel-sel pada kalus sehingga hanya sel-sel yang termutasi yang dapat bertahan dan diregenerasi menjadi tunas. Kemampuan regenerasi yang lebih rendah pada dosis iradiasi yang lebih tinggi dapat disebabkan oleh efek toksik iradiasi terhadap sel dan kemampuan kompetisi sel yang rendah (Patade \& Suprasanna, 2008). Tunas-tunas yang diperoleh kemungkinan besar merupakan mutan solid karena berasal dari satu sel yang mengalami kerusakan genom tanaman pada saat pembelahan sel terjadi di kalus (Maluszynski et al., 1995).

\subsection{Deteksi Perubahan Genetik Keladi Tikus Mutan Asal Kalus}

Deteksi perubahan genetik dilakukan terhadap 11 keladi tikus M1 asal kalus untuk melihat perubahan genetik antar keladi tikus yang dihasilkan. Penelitian ini telah berhasil mendeteksi perubahan genetik pada 11 keladi tikus M1 asal kalus. Pita DNA yang dihasilkan dikategorikan dalam dua kelompok, yaitu pita monomorfik dan pita polimorfik. Pita polimorfik menjadi sumber informasi yang penting dalam deteksi perubahan genetik karena menunjukkan adanya perubahan sekuens DNA pada daerah penempelan primer tersebut. Dari 10 primer yang digunakan, terdapat 9 primer yang menunjukkan perbedaan secara polimorfik. 10 primer yang digunakan menghasilkan total pita sebanyak 69 pita dengan 38 pita polimorfik (Tabel 2). 
Tabel 2: Jumlah pita dan pita polimorfik yang dihasilkan pada 12 keladi tikus (1 kontrol dan 11 mutan M1 keladi tikus asal kalus) menggunakan 10 primer RAPD

\begin{tabular}{|c|c|c|c|c|}
\hline Nama Primer & Sekuens & Ukuran (bp) & Jumlah Pita DNA & Pita Polimorfik \\
\hline OPA-2 & TGCCGAGCTG & $400-1500$ & 6 & 0 \\
\hline OPA-9 & GGGTAACGCC & 950 & 1 & 1 \\
\hline OPA-13 & CAGCACCCAC & $600-2000$ & 8 & 5 \\
\hline OPB-18 & CCACAGCAGT & $850-2500$ & 6 & 1 \\
\hline OPC-5 & GATGACCGCC & $500-2500$ & 10 & 2 \\
\hline OPC-8 & TGGACCGGTG & $750-4000$ & 7 & 4 \\
\hline OPD-8 & GTGTGCCCCA & $600-2400$ & 7 & 5 \\
\hline OPD-20 & ACCCGGTCAC & $600-2600$ & 8 & 11 \\
\hline OPE-3 & CCAGATGCAC & $300-1800$ & 5 & 38 \\
\hline OPE-20 & AACGGTGACC & $300-2700$ & 11 & 69 \\
\hline & & Total & 69 & \\
\hline
\end{tabular}

Perubahan pola pita DNA yang dihasilkan akibat iradiasi gamma antara lain hilangnya pita DNA dan munculnya pita DNA baru jika dibandingkan dengan kontrol. Primer OPE-20 menghasilkan pita polimorfik dengan ukuran 250-1500 bp (Gambar 5). Salah satu perubahan spesifik adalah pada ukuran pita DNA sekitar sekitar 300 bp dan 450 bp pada M-6/2-7. Perubahan-perubahan yang spesifik pada salah satu mutan menandakan bahwa mutan tersebut merupakan mutan yang unik.

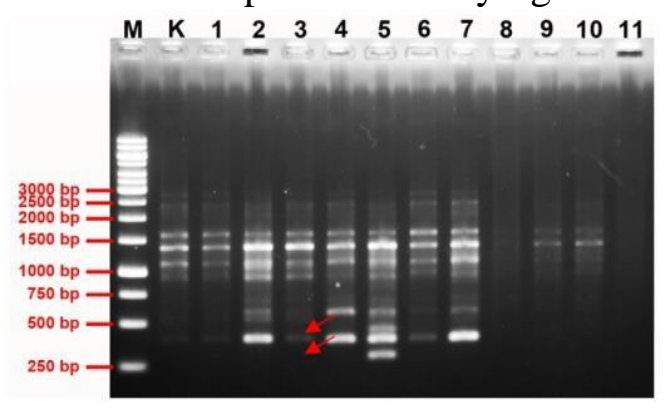

Gambar 5.: Pola pita keladi tikus mutan M1 keladi tikus asal kalus menggunakan primer OPE-20

(M) marker, (K) kontrol, (1) M-6/1-1, (2) M-6/1-3, (3) M-6/2-1, (4) M-6/2-3, (5) M-6/2-7, (6) M-6/3-1, (7) M-6/3-3, (8) M-6/4-1, (9) M-6/5-1, (10) M-6/5-2, (11) M-6/6-1

Analisis kluster juga dilakukan untuk melihat pengelompokan mutan dengan kesamaan genetik yang tinggi antar individu. Gambar 6 menunjukkan dendogram dan pengelompokan mutan hasil analisis kluster yang dilakukan terhadap kontrol dan 11 mutan M1 keladi tikus asal kalus. Pengelompokkan mutan keladi tikus yang dilakukan menunjukkan mutan M-6/2-7 merupakan mutan yang unik dan paling berbeda jika dibandingkan dengan mutan lainnya.

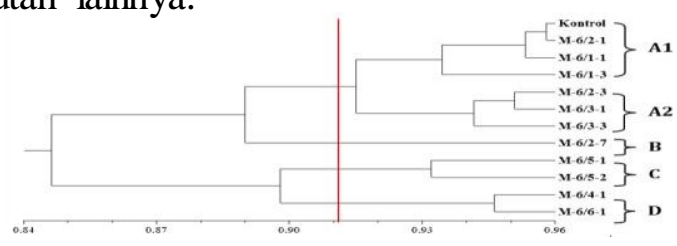

Gambar 6: Dendogram mutan M1 keladi tikus berdasarkan marka mole kuler RAPD Garis vertikal menunjukkan cut-off pada koefisien kesamaan 0,90. 


\subsection{Aplikasi Keladi Tikus Sebagai Pencegah Penyakit kanker}

Analisis GC-MS menujukan bahwa tanaman mutan unggul mengandung senyawa antikanker pada daun dan umbi yang menghasilkan peningkatan kandungan dibanding kontrol dan juga senyawa antikanker baru yang tidak ditemukan pada tanaman kontrol. Hasil penelitian yang sudah diperoleh selama penelitian 5 tahun terakhir yaitu diperoleh teknologi produksi bibit dari keladi tikus, tanaman mutan yang memiliki keragaman genetik dan mutan unggul yang memliki kandungan antikanker yang tinggi. Tanaman keladi tikus klon unggul yang dihasilkan dapat digunakan sebagai minuman fungisional dan obat yang bermanfaat untuk mencegah dan mengobati penyakit kanker dalam tubuh manusia. Masyarakat Indonesia sangat membutuhkan obat antikanker karena kanker adalah salah satu penyebab kematian utama, secara spesifik kanker payudara merupakan jenis kanker yang paling umum berdasarkan data Kementerian Kesehatan tahun 2010-2013 (Kementerian Kesehatan, 2015).

Bahan baku obat antikanker dari keladi tikus sangat dibutuhkan untuk mengatasi masalah penyakit kanker. Diharapkan produksi tanaman keladi tikus unggul dapat menjawab masalah masyarakat dan dapat meningkatkan kesejahteraan masyarakat Indonesia. Penelitian lanjutan untuk menguji aktivitas antikanker klon mutan unggul keladi tikus akan dilakukan agar dapat mengembangkan keladi tikus sebagai bahan baku obat antikanker.

\section{Kesimpulan}

Dari penelitian pengembangan keladi tikus ini dapat disimpulkan :

1. Teknologi kultur jaringan sudah berhasil untuk memproduksi tunas keladi tikus pada media Murashige Skoog (MS) yang ditambahkan dengan 0,5 mg/L $2.4 \mathrm{D}$ dan $0,1 \mathrm{mg} / \mathrm{L}$ kinetin.

2. Tanaman mutan yang beragam secara morfologi, genetik, dan kandungan kimia telah dihasilkan melalui mutasi sinar gamma pada dosis 6 gray.

3. Tanaman yang diradisiasi dengan sinar gamma telah dideteksi terjadi perubahan genetik berdasarkan marka molekuler RAPD.

4. Tanaman mutan mengandung senyawa bioaktif antikanker yang meningkat dibandingkan dengan tanaman kontrol, serta mengandung senyawa antikanker baru yang tidak ditemukan di kontrol.

\section{Saran}

Penelitian keladi tikus mutan unggul perlu dilakukan lebih lanjut hingga diperoleh produk minuman kesehatan dan obat yang berfungsi untuk mencegah dan mengobati kanker

\section{Daftar pustaka}

Choo, C.Y., Chan, K.L., Takeya, K. \&Itokawa, H. (2001). Cytotoxic activity of Typhoniumflagelliforme (Araceae). Phytotherapy Research, 15:260-262.

Doyle, J.J. \& Doyle, J.L. 1987. A rapid DNA isolation procedure for small quantities of fresh leaf tissue. Pythochemical Bulletin, 19:11-15.

Essai. (1986). Medicinal herbs index in Indonesia. PT Essai indonesia. 357 hal. 
Hoesen DSH. (2007). Pertumbuhan dan perkembangan tunas Typhonium secara in vitro. Berita Biologi. 8(5): 413-422.

Kementrian Kesehatan Republik Indonesia. (2015). Pusat Data dan Informasi. 8 hal.

Lai, C.S., Mas, R.H., Nair, N.K., Mansor, S.M. \&Navaratnam, V. (2010). Chemical constituents and in vitro anticancer activity of Typhoniumflagelliforme (Araceae).Journal of Ethnopharmocology, 127:486-494.

Lai, C.S., Mas, R.H.M.H., Nair, N.K., Majid, M.I.A., Mansor, S.M. \&Navaratnam, V. (2008).

Typhonium flagelliformeinhibits cancer cell growth in vitro and induces apoptosis: An evaluation by the bioactivity guided approach. Journal of Ethnopharmacology, 118:14-20.

Maluszynski, M., Ahloowalia, B.S. \& Sigurbjornsoon, B. (1995). Application of in vivo and in vitro mutation techniques for crop improvement. Euphytica, 85:303-315.

Mohan S, Bustamam A, Ibrahim S, Al-Zubairi AS, Aspollah M. (2008). Anticancerous Effect of Typhonium flagelliforme on Human T4-Lymphoblastoid Cell Line CEM-ss. Journal of Pharmacology and Toxicology, 3(6): 449-456.

Mohan, S., Abdul, A.B., Abdelwahab, S.I., Al-Zubairi, A.S., Aspollah, S.M., Abdullah, R., Taha, M.M., Beng, N.K. \& Isa N.M. (2010). Typhonium flagelliforme inhibits the proliferation of murine leukemia WEHI-3 cells in vitro and induces apoptosis in vivo. Leukimia Research, 34:1483-1492.

Nei, M. \& Li, W.H. (1979). Mathematical model for studying genetic variation in terms of restriction endonucleases. Proceedings of the National Academy of Sciences of the United States of America, 74:5267-5273.

Nobakht, G. M., Kadir, M. A., dan Stanslas, J. (2009). In Vitro Mass Propagation of Typhonium flagelliforme as Affected by Plant Growth Regulators. African Journal of Biotechnology, 8:6840 - 6843.

Patade, V.Y. \& Suprasanna, P. (2008). Radiation induced in vitro mutagenesis for sugarcane improvement. Sugar Tech, 10:14-19.

Puchooa, D. (2005). In vitro mutation breeding of Anthurium by gamma radiation. International Journal of Agriculture \& Biology, 7:11-20.

Rohlf, F.J. (2008). NTSYSpc : Numerical Taxonomy System, ver. 2.02. Exeter Publishing, Ltd.: Setauket, New York.

Sianipar NF, Ariandana, Maarisit W. (2015a). Detection of Gamma-Irradiated Mutant of Rodent Tuber (Typhonium flagelliforme Lodd.) In Vitro Culture by RAPD Molecular Marker. Procedia Chemistry Elsevier, 14: 285 - 294.

Sianipar NF, Laurent D, Purnamaningsih R, Darwati I. (2015b). Genetic Variation of the First Generation of Rodent Tuber (Typhonium flagelliforme Lodd.) Mutants Based on RAPD Molecular Markers. HAYATI Journal of Biosciences, 22 (2).

Sianipar NF, Maarisit W, Valencia A. (2013a). Toxic activities of hexane extract and column chromatography fractions of rodent tuber (Typhonium flagelliforme Lodd.) on Artemia salina. Indonesian Journal of Agricultural Science, 14(1): 1-7.

Sianipar NF, Wantho A, Rustikawati, Maarisit, W. (2013b). The effect of gamma irradiation on growth response of rodent tuber (Typhonium flagelliforme Lodd.) mutant in vitro culture. HAYATI Journal of Bioscience, 20 (2): 51-56.

Syahid SF, Kristina NN. (2007). Induksi dan regenerasi kalus keladi tikus (Typhonium flagelliforme Lodd.) secara in vitro. J Littri 13:142-146.

Syahid SF. (2007). Perbanyakan keladi tikus ( Typhonium flagelliforme Lodd) secara in vitro. Warta Puslitbangbun 13 (3) : 19-20. 
Syahid SF. (2008). Keragaman morfologi, pertumbuhan, produksi, mutu dan fitokimia keladi tikus (Typhonium flagelliformeLodd.) Blume asal variasi somaklonal. Journal Littri 14 (3):113-118.

Yasmin, S., Knha, I., Khatri, A., Seema, N., Siddiqui, M.A. \& Bibi, S. (2011). Plant regeneration from irradiated embryogenic callus of sugarcane. Pakistan Journal of Botany, 43:2423-2426. 